\title{
Deep Water Status in Southwestern Tunisia
}

\author{
Thouraya Zemni' ${ }^{1}$, Mohsen Ben Alaya ${ }^{1}$, Fouad Zargouni1 ${ }^{1}$, Lahmaidi Moumni2 \\ ${ }^{1}$ Department of Geology, University of Sciences, Tunis, Tunisia \\ ${ }^{2}$ Agriculture and Water Resources Ministry, Tunis, Tunisia \\ Email: thourayazemni@gmail.com
}

Received 7 April 2016; accepted 24 May 2016; published 27 May 2016

Copyright (C) 2016 by authors and Scientific Research Publishing Inc.

This work is licensed under the Creative Commons Attribution International License (CC BY). http://creativecommons.org/licenses/by/4.0/

(c) (†) Open Access

\begin{abstract}
Due to the water demand growth in southwestern Tunisia, particularly in Segui Gafsa-Tozeur area, the Tunisian Government launched a research program for new water resources in the lower Cretaceous layers within the Hauterivian and Barremian age. The present study highlights the major results of this project and defines the ability of the Barremian and Hauterivian series to be or not as good usable aquifers in this region. Seismic data show that the studied levels are located in deep trough with a very high depth. The water collected from the drilled wells in this region shows a very high salinity $(80 \mathrm{~g} / \mathrm{l}$ to $130 \mathrm{~g} / \mathrm{l})$ with a very low water level $(-162 \mathrm{~m} / \mathrm{TN})$. These water levels are in hydrological isolation by faulting (faults trending NE-SW and NW-SE) with the Jerid area, where these layers are good water bearing. Thus, the studied series can't be considered as encouraging usable aquifers in the future. These results are crucial to make a decision and represent the guideline for research strategies in South-West Tunisia. Consequently, the government focuses on water search within the Turonian level which showed much more encouraging signs.
\end{abstract}

\section{Keywords}

Southwestern Tunisia, Barremian, Hauterivian, Aquifers, Salinity

\section{Introduction}

In southern Tunisia, groundwater is the main natural resource of the region. Thus, the Continental Intercalaire [1]-[5] is an immense multilayered aquifer which is Lower Cretaceous, Barremian and Hauterivien age. This aquifer is the deepest and largest one in the south of the country. It covers a large area of Algeria, Tunisia and Libya and extends on approximately 840,000 square kilometers [6].

Nevertheless, in the Tunisian side, in the Segui Gafsa-Tozeur region, many questions arise and the Barremian-Hauterivian aquifer has not been studied till now. Also, due to the large population and development increase, water demand is in perpetual growth. So the Tunisian government launched a development program to find and assess new water resources [7] and began by the deep series of Barremian and Hauterivian which were 
hosting a good aquifer in the zone of Jerid.

In this study, due to the important depth of Lower Cretaceous series, we will use deep wells data and seismic reflection [8]-[11] to show the susceptibility of Barremian and Hautervien series to be good or not as usable aquifers and therefore guide water research strategies in this area.

\section{Study Area}

The study area mainly occupied by the plains of Segui, is located in south Tunisia and north of the Saharian platform. Administratively, it is attached to the delegation of Gafsa and Tozeur. It covers an area of about 1000 square kilometers of which $80 \%$ belongs to Gafsa and have an E-W general direction. It collects water runoff and alluvial material from: Gafsa-Metlaoui chain, Jebel Sehib and Jebel Berda in the north and by the mountains of the northern Chott chain in south. It is limited to the west by Jerid and chott El Gharsa (Figure 1).

\section{Geology}

Segui region is located in the extreme South of the Tunisian Atlas and it's characterized by the East-West chott features which represent the most southern structures of the Atlasic domain [12] and it's affected in its southwestern part by the NW-SE Negrine Tozeur fault (Figure 2) [13] [14].

A geological map of the study area is shown in Figure 3. The oldest deposits of the Lower Cretaceous limestone, mudstone and shale are found in the South-East and dip to the West. These formations overlay on the Jurassic bedrocks. The stratigraphic units of Lower Cretaceous [15] [16] in this region are shown in Table 1. The units of Barremian (Sidi Aich Formation) and Hauterivian (Boudinar Formation) consist of two main aquifer level well known in the nearest zone of Jerid. These units are characterized in Segui region trough the data of the deep Guantass-1 (GNT) well (located at the North East of Chott El Gharsa with a total depth of $4000 \mathrm{~m}$ ) and Sehib-1 (SHB) well (terminated at $2700 \mathrm{~m}$ ). These two wells are important but cannot give a detailed idea about the lateral evolution of the aquifer and can explain why it' not well studied till now.

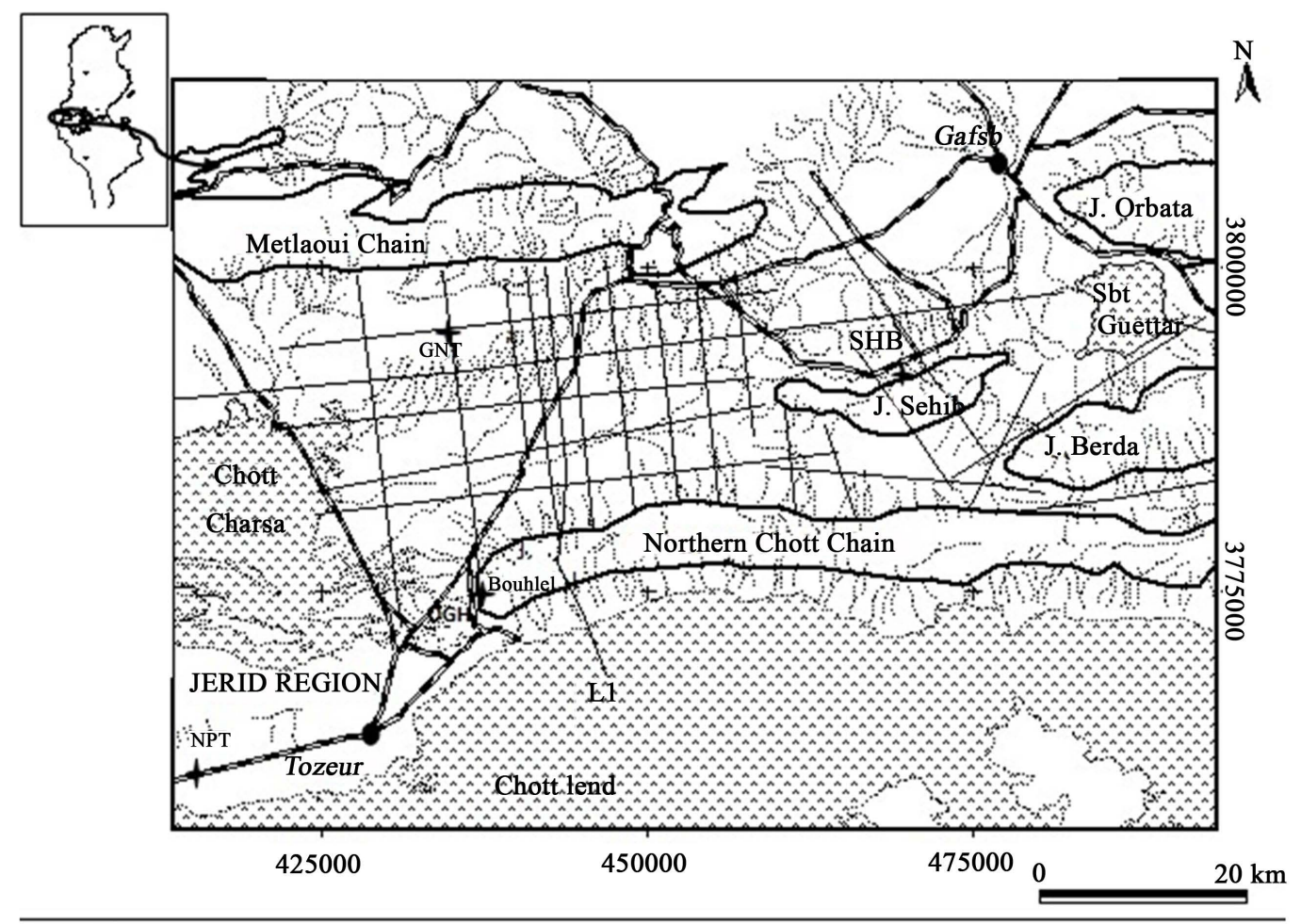

Legend:

-.- Waterways

- Seismic line

+ Well

rad

City

Figure 1. Location of study area. 


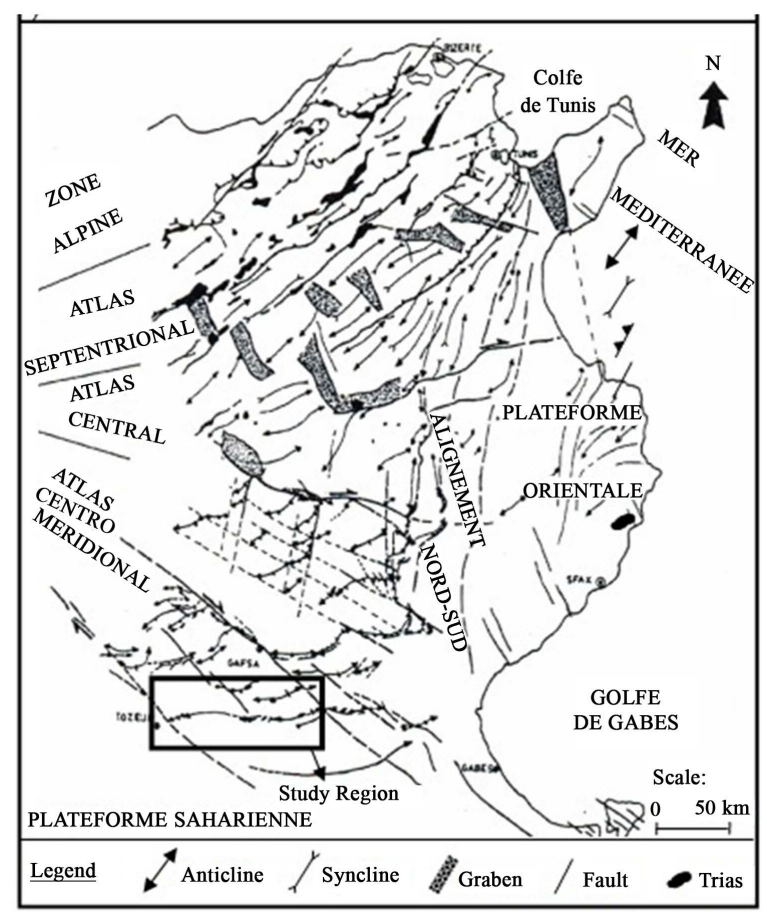

Figure 2. Structural location of study area [13].

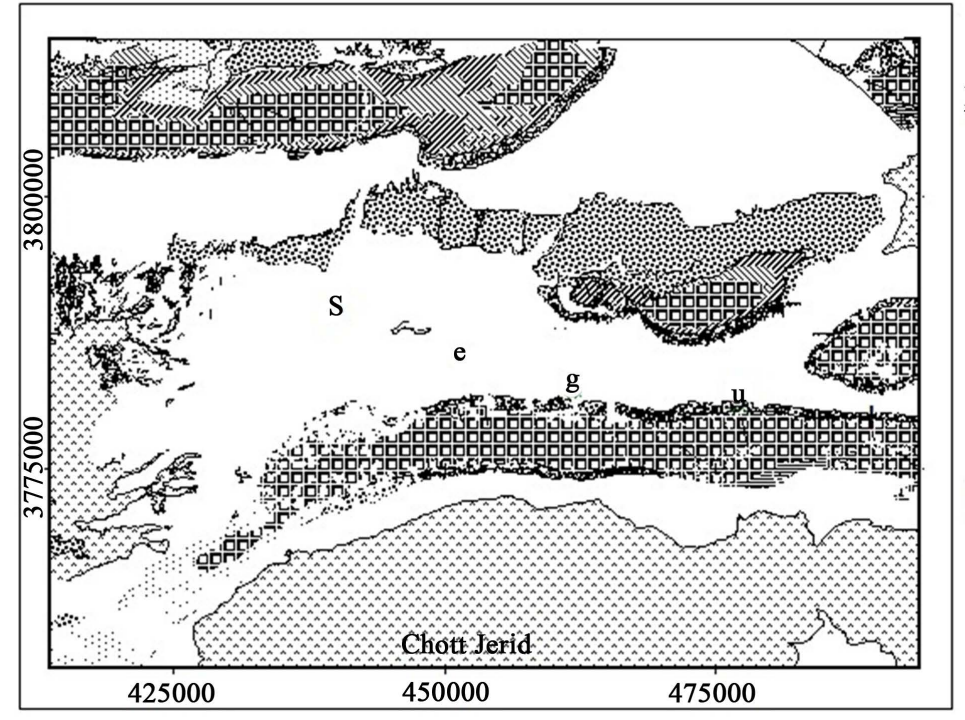

Legend:

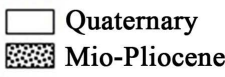

Mio-Plioce

Oligocene

WIIA Eocene

Paleocene

Upper Cretaceous

琶 Lower Cretaceous

Es?

Scale:

$0 \quad 20 \mathrm{Km}$

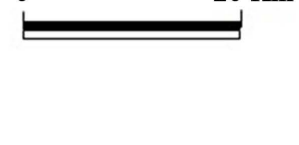

Figure 3. Geological map of study area.

Table 1. Stratigraphic units and geological formations in study region.

\begin{tabular}{lll}
\hline Stratigraphic unit & & Formation name/Lithology \\
\hline Lower & Albian & Lower Zebbag/Limestone and domlomite \\
Cretaceous & Aptian & Orbata/Dolomite, limestone and marl \\
& Barremian & Sidi Aich/Sand and sandstone \\
& Hauter-Barrem & Bouhedma/Clay and dolomite \\
& Hauterivian & Boudinar/Sand, sadstone and clay \\
& Valanginian & Melloussi/Clay, limestone and sand \\
& Berriasian & Sidi Khlif/Clay and limestone \\
Turassic & Tithonian & Nara/Limestone, dolomite and clay \\
\hline
\end{tabular}




\subsection{Barremian}

It's known as sandy "Sidi Aich" foramtion. It's about $92 \mathrm{~m}$ of thikness in Guantass well with $3229 \mathrm{~m}$ deep and mainly consists on white sand and sandstone interbedded with plastic gray clays. In the top of the formation, there is a thin layer of dolomite. These deposits represent a deltaic environment with alluvial plain deposits [17].

In Sehib well, the Barremian of $115 \mathrm{~m}$ thick and deep $2330 \mathrm{~m}$, is mainly represented by a thick sand unit interbedded by some dolomitic and clays levels. In the top, there is a saccharoid dolomite with an ostrcaufauna composed of Cyterelle sp., Dolocytheridea sp., Cytherella parallela, krithe sp. [18].

\subsection{Hauterivian}

The Hauterivian is represented by Boudinar Formation. In Segui, It's only recognized in Guantass well at a depth of $3625 \mathrm{~m}$ and mainly known by sand, some clays bed, anhydrite and lignite with a total thickness of 247 m.

In the nearest southwest region of Jerid, Boudinar formation is recognized also by sand and it's more interbedded by sandstone and clays beds.

Sandy Hauterivian level of Boudinar is topped by clays levels of Bouhedma formation of upper Hauterivainlower Barremian age.

Well to well correlation of these geological formations of Barremian and Hauterivian (Figure 4) shows important variations in thickness and depth from Sehib towards Guantass structure and south region. This variation gives a view about the subsurface structures variations of upper zone and lower zones.

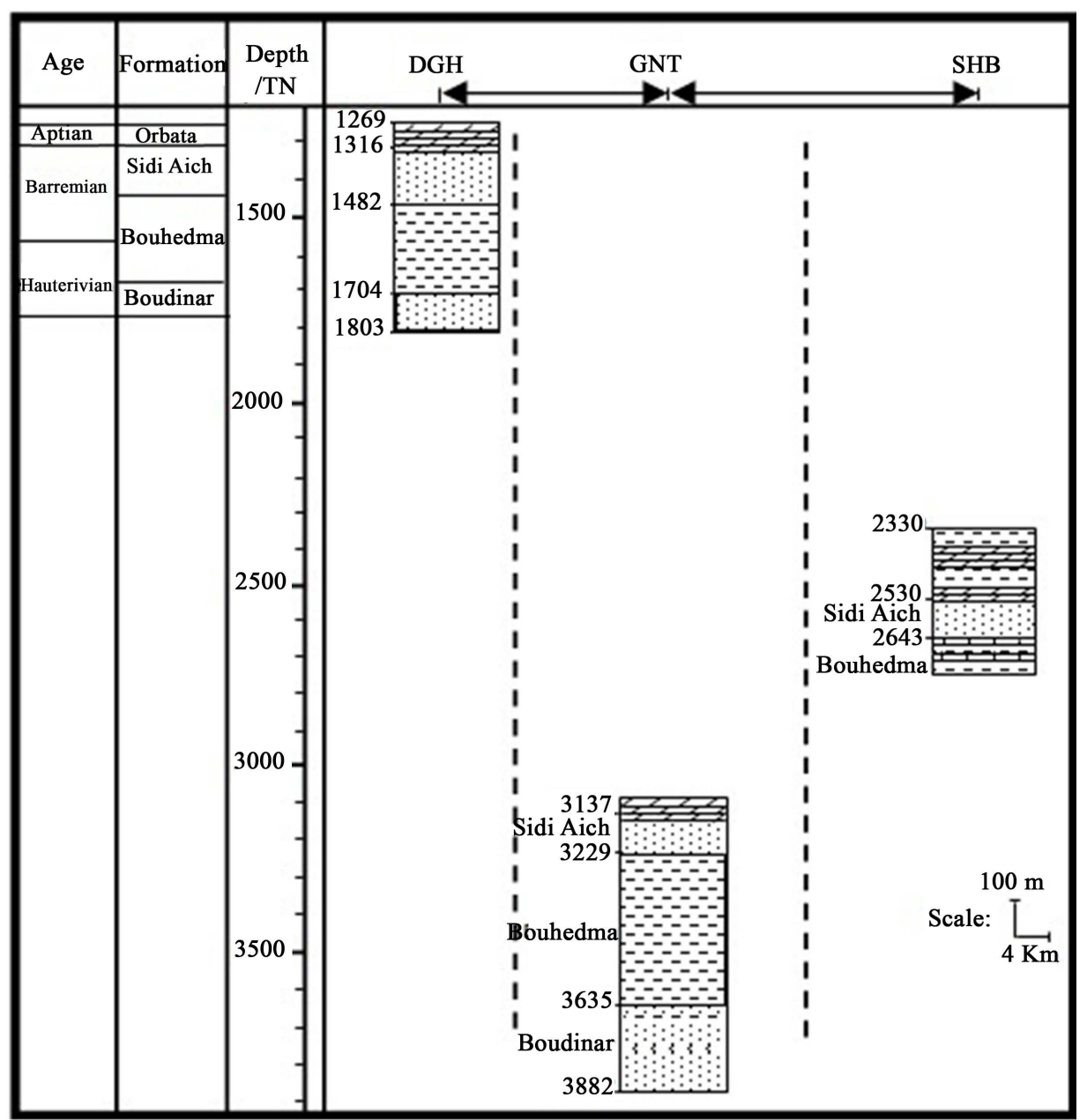

Figure 4. Correlation between DGH-GNT-SHB. 
The exposed correlation between Degache (DGH)-Guantass and Sehib well reveal that in the Guatass well Sidi Aich and Boudinar formation are the deepest one in the region and they presents a thinning and elevation of level towards south Segui, Jerid region and Jebel Sehib.

\section{Hydrogeology}

The aquifer of Continental Intercalaire (CI) is an important groundwater reservoir within the Lower Cretaceous series [1]-[3] covering southern Tunisia (Figure 5). The study area occupies the Northern limit of the reservoir extension domain, where the continuity and the existence of this water-bearing reservoir are not yet clear and proved, which is the main objective of this paper.

In Jerid, located in the South-Western boundary of the study area, The aquifer of Continental Intercalaire (CI) was exploited by 25 deep water wells that provided good results regarding standpoint depth, water chemical quality, flow and groundwater level [5] [11] [19]. Otherwise, to the North of the study region, in the Guantass well located at $26 \mathrm{~km}$ of Degache well, we find water in Hauterivian series at much more important depth (3636 $\mathrm{m}$ ) and much higher salinity of about $130 \mathrm{~g} / \mathrm{l}$. The increased depth is explained by the fault action allowing the individualization of Guantass structure. To the East, water was found in the Barremian level at $2530 \mathrm{~m} / \mathrm{TN}$ in Sehib well with high salinity equal to $80 \mathrm{~g} / \mathrm{l}$, and water level of $-162 \mathrm{~m} / \mathrm{TN}$.

Referring to this bad result, the Sehib well operations was immediately stopped and the Tunisian government launched a project to study the ability of the Barremian and Hauterivien series to be good aquifer levels or not on this area.

A map showing depth variations of these series and their geometry in the study area was done using seismic data. It gives a clear and precise overview of depth and structures of these series in Segui region.

\section{Method and Contribution of Seismic Reflexion}

Existing deep wells and seismic data have been provided by the Tunisian National Oil Company (ETAP) and the Water Resources Department of Tunisia (DGRE) Seismic data allowed us to characterize and precise subsurface geometry and depth of studied levels in the whole region, that is mainly trough seismic lines. Twenty four seismic lines of a total $661.5 \mathrm{Km}$ covering the study area (Figure 1) have been interpreted. The first step was to calibrate the seismic section using the Guantass well based on data of the time-depth curve. This step has allowed us to make the correspondence between the different formations crossed by the well and their seismic response [20] [21].

The seismic lines analysis shows that the Aptian dolomite is the better level having high amplitude which can be followed on all the sections. Also, Aptian dolomite is overlaying the top of sandy Sidi Aich Formation. Thus the structural characterization of the whole unit of Barremian and Hauterivien series is based on those Aptian dolomitic levels.

Aptian dolomite is highlighted in the different seismic lines. The interpolation of this level between different lines allows us to achieve isochrone map of Segui region [22]. Then, based on the time-depth curve, we generate the depth map, linking equal depth zone.

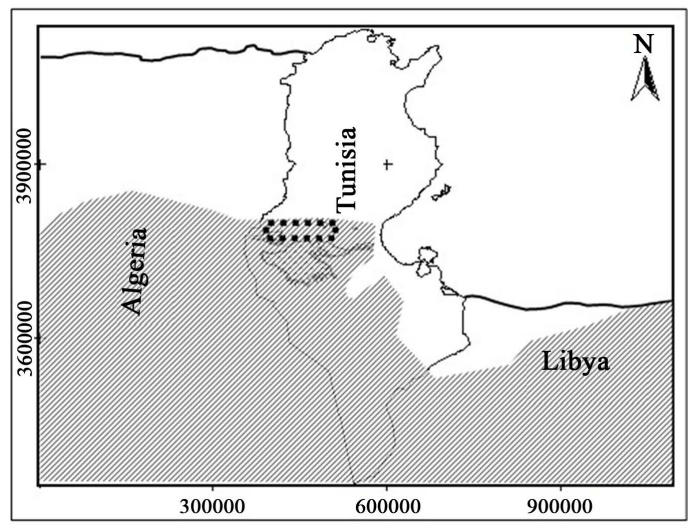

Legend:

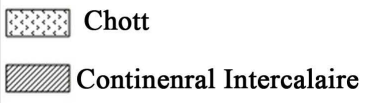

:..... Study region

Scale:

$0 \quad 200 \mathrm{Km}$

Figure 5. Continental Intercalaire extension [3]. 


\section{Results and Interpretations}

The depth map (Figure 6) allowed us to characterize the depth and the subsurface geometry of the lower Cretaceous series and to characterize different structural features that exist in Segui Gafsa-Tozeur area.

We deduce that, Aptian dolomite which overlay Hauterivian and Barremian is very deep, exceeding in some localities $3500 \mathrm{~m}$. Also we figure out the existence of high area called Gantass fold that is formed by large reverse NW-SE trending fault. Going further to the South, the Cretaceous series become more and deeper especially in Segui basin, then their depth increase more and more toward Jebel Sidi Bouhlel.

An important seismic lines, allowed us to interpret and explain these results (Figure 7).

Based on data of Guantass well, seismic line L1 and time-depth convertion curve, we could achieve from the L1 profile a geoseismic section which shows more clearly the deep structure of this area (Figure 8).

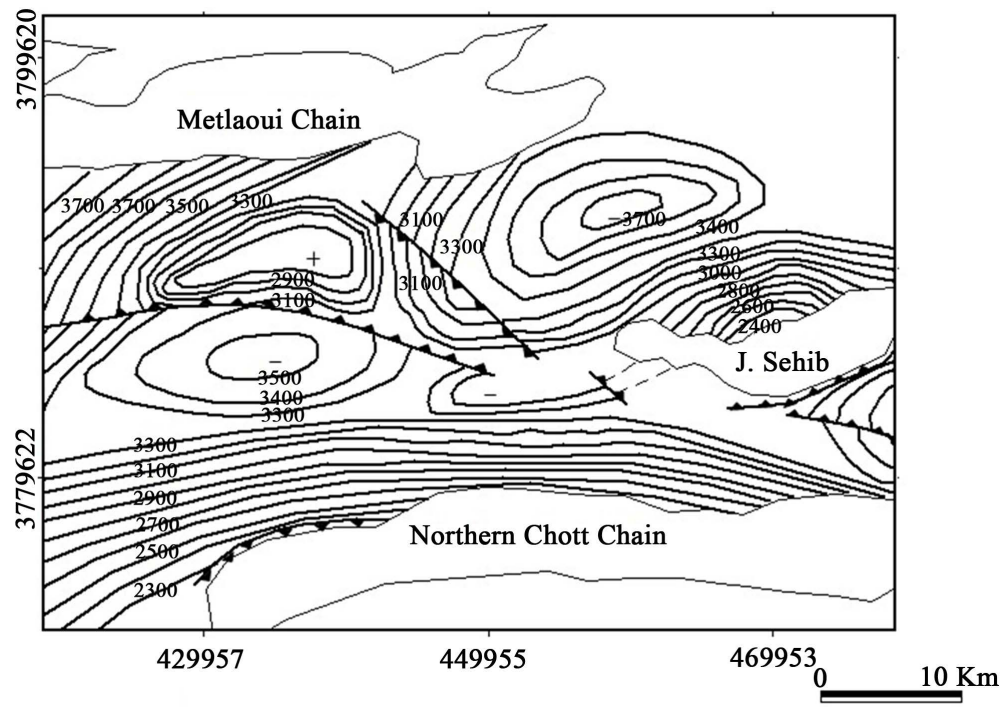

Figure 6. Depth map of aptian dolomite.

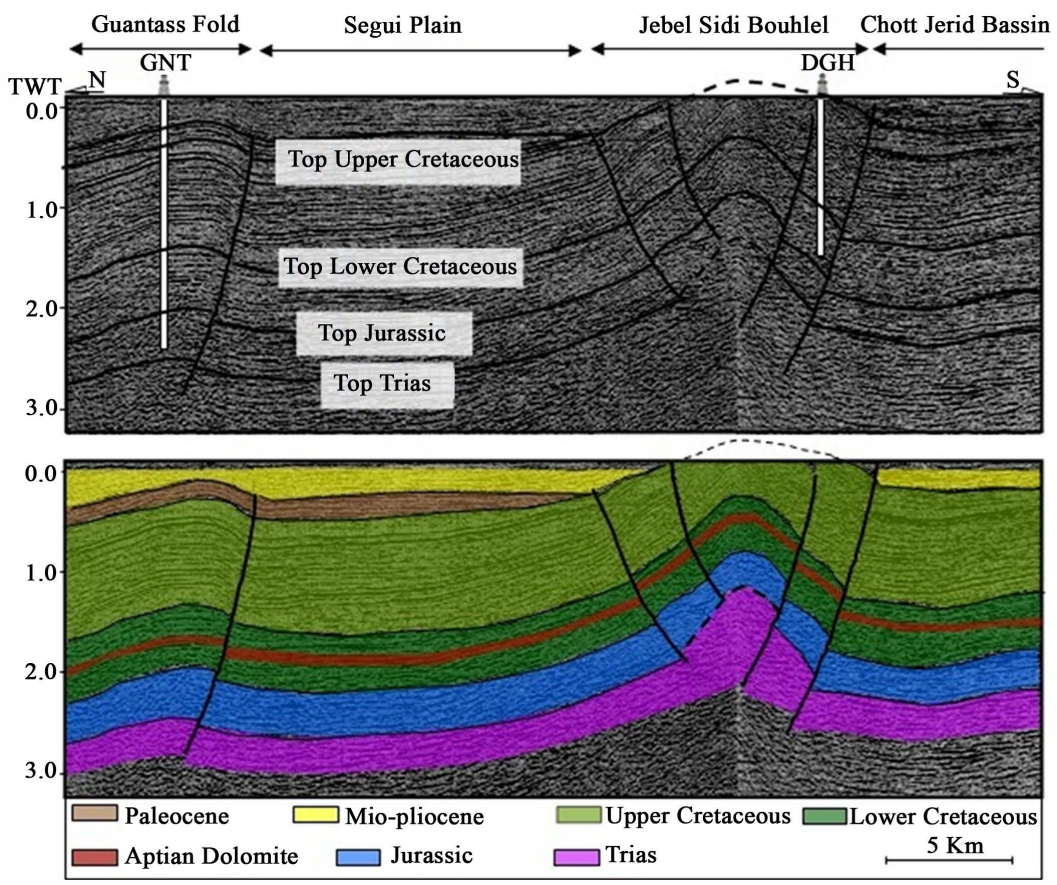

Figure 7. Seismic profile L1. 


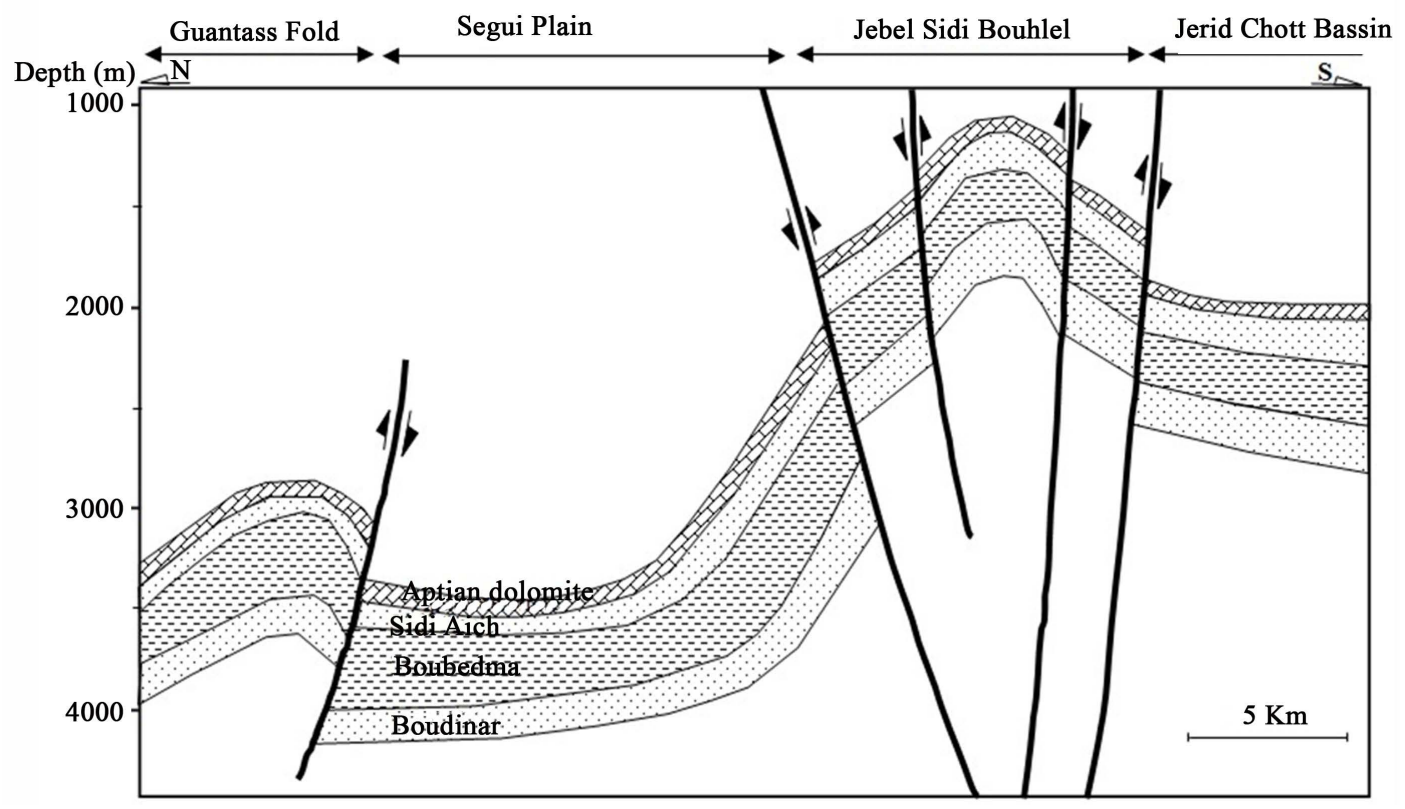

Figure 8. Geoseismic section of seismic profile L1.

The structure of the region is characterized mainly by the action of 3 main reverse faults, a high zone of Jebel Sidi Bouhlel and Guantass fold. We also deduce that Sidi Aich and Boudinar formation show in the Bled Segui syncline a collapse caused by the fault of the southern part of Guantass fold, depths of Boudinar formation exceed in some places $3500 \mathrm{~m}$.

Depth map and seismic line L1 show the tectonic role in isolation of Jebel Sidi Bouhlel region in south and Segui region in north. This reveals and show also the non water communication between these two zones related to the tectonic action which place permeable levels of Jebel Sidi Bouhlel in front with those non permeable of Segui plain.

Thus, high salinity and its significant increase compared to the neighboring region of Jerid are in support of the total water isolation from Jerid region. This also shows that the flows from North-West to South-West proven in Jerid area [8] do not reach the plain Segui for its water and structural isolation.

\section{Conclusions}

Based on the Guantass and Sehib well data, seismic lines and depth map, it is clearly come into view:

-A high deepening of Barremian and Hauterivien series in Segui region which exceeds in some places 3500 $\mathrm{m}$;

-A high salinity of water within Barremian $(80 \mathrm{~g} / \mathrm{l}$ in Sehib well) and Huterivian aquifers $(130 \mathrm{~g} / \mathrm{l}$ in Guantass well);

-A low groundwater level which is of $-162 \mathrm{~m} / \mathrm{TN}$;

-A total hydrological and structural isolation of these aquifers related to these on the neighboring area of Jerid, where these levels are considered as good aquifers.

As conclusion, the Barremian and Hauterivian series in Segui region cannot be considered as good water bearing reservoirs.

These results are crucial to make a decision and represent the guideline for research strategies in South-West Tunisia. So, search of solutions to find usable water resource has been launched in other shallower permeable series of Turonian age [23].

\section{References}

[1] Mamou, A. (1990) Caractéristiques et évaluation des ressources en eau du sud tunisien. Es Sciences Thesis, University Paris Sud, France, 426. 
[2] OSS (2003) Système Aquifère du Sahara Septentrional. Vol. 2: Hydrogéologie. Projet SASS. Report of the General Direction of Water Resources.

[3] OSS (2008) Système Aquifère du Sahara Septentrional (Algérie-Tunisie-Lybie), Gestion concertée d'un bassin transfrontalier. Report of the General Direction of Water Resources.

[4] Chalbaoui, M. and Ben Dhia, H. (2004) Principales caractéristiques des réservoirs du sud-ouest tunisien. Comptes Rendus Geoscience, 336, 1191-1198. http://dx.doi.org/10.1016/j.crte.2004.07.002

[5] Kamel, S. (2007) Caractérisation hydrodynamique et géochimique des aquifères du Djérid (Sud Ouest Tunisien). PhD Thesis, University of Tunis II, Tunisia.

[6] UNESCO (1972) Etude des Ressources en Eau du Sahara Septentrional (Algérie et Tunisie). Rapport sur les Résultats du Projet (Conclusions et Recommandations), Report of the General Direction of Water Resources.

[7] DGRE (2011) Etude Hydrogéologique des Ségui Gafsa-Tozeur-Kébili. Report of the General Direction of Water Resources, $55 \mathrm{p}$.

[8] Jaffal, M., Kchikach, A., Lefort, J.P. and Hanich, L. (2002) Contribution à l'étude d'une partie du bassin d'Essaouira (Maroc) par sismique réflexion. Comptes Rendus de l'Académie des Sciences, 334, 229-234.

[9] Zouhri, L., Gorini, C., Lamouroux, C., Vachard, D. and Dakki, M. (2003) Interprétation hydrogéologique de l'aquifère des bassins sud-rifains (Maroc): Apport de la sismique réflexion. Comptes Rendus Geoscience, 335, 319-326. http://dx.doi.org/10.1016/S1631-0713(03)00052-X

[10] Larroque, F. and Dupuy, A. (2004) Apports de la méthode sismique réflexion haute résolution à l'identification des structures profondes des formations tertiaires en Médoc (Gironde, France): Implications hydrogéologiques. Comptes Rendus Geoscience, 336, 1111-1120. http://dx.doi.org/10.1016/j.crte.2004.04.009

[11] Guellala, R. ( 2010) Etude géologique et hydrogéologique des séries crétacées inférieures du Jérid (Sud-Ouest de la Tunisie). Apports des méthodes géophysiques. PhD Thesis, University of Tunis II, Tunisia.

[12] Saadi, A. (1983) Etude sedimentologique et structurale de la partie Est de la Charne Nord des Chotts. Es Sciences Thesis, University Tunis II, Tunisia.

[13] Zargouni, F. (1985) Tectonique de l'Atlas méridional de Tunisie, évolution géométrique et cinématique des structures en zone de cisaillement. Es Sciences Thesis, University Louis Pasteur, France.

[14] Zargouni, F., Rabia, M.Ch. and Abbès, Ch. (1985) Rôle des couloirs de cisaillement de Gafsa et de Négrine-Tozeur dans la structuration du faisceau des plis des Chotts, éléments de l'accident sud-Atlasique. Comptes Rendus de l'Académie des Sciences, 301, 831-834.

[15] Burollet, P.F., Memmi, L. and M'Rabet, A. (1983) Le Crétacé inférieur de Tunisie. Aperçu stratigraphique et sédimentologique. Zitteliana, Munchen, 20, 255-264.

[16] Ben Youssef, M., Biely, A. and Memmi, L. (1984) Mise au point sur la formation Orbata en Tunisie méridionale in Journée sur les nomenclatures et les classifications Soc des Sc de la Terre de Tunisie Résumés: 7.

[17] Schell (1999) End of Well Report of Gantass-1. Scell Report, Tunisia, 121 p.

[18] Amri, A., Ben Youssef, M. and Ghanmi, M. (2004) Biostratigraphie, paléoécologie de l'intervalle HauterivienPaléocène du massif de Séhib (région de gafsa), corrélation avec les zones adjacentes, implication géodynamique. Geological Service Notes, 72, 18.

[19] Moumni, L. (2001) La nappe de Sidi Aich ou «ContinentalIntercalaire» du Jérid. Tunisie. Direction Générale des Ressources en Eau, Report of the General Direction of Water Resources, 1-52.

[20] Inoubli, M.H. (1993) Conception d'une méthodologie d'interprétation en géophysique: Apport du traitement et de l'inversion de données sismiques réelles. Es Sciences Thesis, University of Tunis II, Tunisia.

[21] Zemni, T. (2004) Construction de coupes chronostratigraphiques à partir des sections sismiques. Graduation Project, University of Tunis II, Tunisia.

[22] Zouaghi, T., Bédir, M. and Inoubli, M.H. (2005) 2D Seismic Interpretation of Strike-Slip Faulting, Salt Tectonics, and Cretaceous Unconformities, Atlas Mountains, Central Tunisia. Journal of African Earth Sciences, 43, 464-486. http://dx.doi.org/10.1016/j.jafrearsci.2005.09.010

[23] DGRE (2015) Programme d'investissement dans le secteur de l'eau II: Note sur la réalisation de deux forages de reconnaissance Lot 1: Segui Turonien - Lot 2: Belkhir Turonien. Note of the General Direction of Water Resources. 